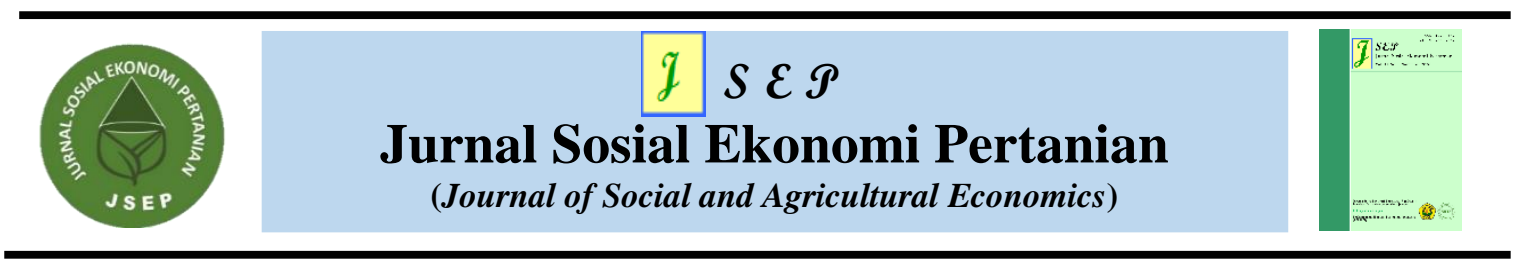

\title{
FACTORS AFFECTING FARMER'S CLIMATE RISK PERCEPTION IN DEVELOPED AND DEVELOPING COUNTRIES: EVIDENCE FROM SWITZERLAND AND GHANA
}

\author{
Rokhani $^{1}$, Ahmad Asrofi ${ }^{2}$, Ahmad Fatikhul Khasan ${ }^{2,3}$ \\ ${ }^{1}$ Department of Agricultural Extension, University of Jember, Indonesia \\ ${ }^{2}$ Department of Agribusiness, University of Jember, Indonesia \\ ${ }^{3}$ Doctoral Study Program of Agricultural Science, University of Jember, Indonesia \\ email: rokhani@unej.ac.id; +6281310480035
}

Article received: 24/10/2020 Article revised:19/11/2020 Article published: 30/11/2020

\begin{abstract}
Climate change is the primary challenge of agricultural production in developing and developed countries. Farmers' perception of climate change is the critical driver in encouraging farmers to take autonomous adaptation practices. Thus, this study aimed to identify factors affecting farmers' perception of climate change in developing and developed countries and take Ghana and Switzerland as the study cases. The study used data from 378 cocoa farmers in Ghana and 109 farmers in Switzerland. The data was obtained from a structured interview and survey and contained socio-economic and farm characteristics of farmers. This study employed an ordered probit regression to estimate the factors affecting farmers' perception of climate change. The results show that landholding, farm income, and education significantly affect farmer perception of climate change. Landholding and farm income significantly affect farmer perception of climate change in Switzerland and Ghana. But, education only significantly affects the farmers' perception of climate change in Switzerland. Meanwhile, age and crops/livestock ownership does not significantly affect farmers' perception of climate change in Ghana and Switzerland. The results also show that Switzerland's farmers have a stronger perception of climate change than farmers in Ghana.
\end{abstract}

Keywords: climate risk perception, climate change perception, Ghana, Switzerland

\begin{abstract}
ABSTRAK
Perubahan iklim adalah tantangan utama produksi pertanian di negara berkembang dan maju. Persepsi petani terhadap perubahan iklim merupakan pendorong penting dalam mendorong petani untuk melakukan praktik adaptasi secara otonom. Oleh karena itu, penelitian ini bertujuan untuk mengidentifikasi faktor-faktor yang mempengaruhi persepsi petani tentang perubahan iklim di negara berkembang dan negara maju dan mengambil kasus studi Ghana dan Swiss. Studi ini menggunakan data dari 378 petani kakao di Ghana dan 109 petani di Swiss. Data diperoleh dari wawancara dan survei terstruktur dan berisi tentang karakteristik sosial ekonomi dan usahatani petani. Studi studi ini menggunakan regresi probit berurutan untuk memperkirakan faktor-faktor yang mempengaruhi persepsi petani tentang perubahan iklim. Hasil penelitian menunjukkan bahwa kepemilikan lahan, pendapatan usahatani, dan pendidikan berpengaruh signifikan terhadap persepsi petani tentang perubahan iklim. Kepemilikan tanah dan pendapatan pertanian secara signifikan mempengaruhi persepsi petani tentang perubahan iklim di Swiss dan Ghana. Tapi, pendidikan hanya mempengaruhi persepsi petani tentang perubahan iklim di Swiss. Sedangkan umur dan kepemilikan tanaman / ternak tidak berpengaruh signifikan terhadap persepsi petani terhadap perubahan iklim di Ghana dan Swiss. Hasilnya juga menunjukkan bahwa petani Swiss memiliki persepsi yang lebih kuat tentang perubahan iklim daripada petani di Ghana.
\end{abstract}

Kata kunci: persepsi risiko perubahan iklim, persepsi terhadap perubahan iklim, Ghana, Swiss

How to cite: Rokhani, Asrofi, A., Khasan, A.F., Kreft, C.S., Hubber, R., Wupper, D.J., Finger, R., Oyekale, A.S. (2020). Factors Affecting Farmer's Climate Risk Perception in Developed and Developing Countries: Evidence From Switzerland and Ghana. JSEP: Jurnal Sosial Ekonomi Pertanian, 13(3): 296306. 


\section{INTRODUCTION}

Climate plays a critical role in the agricultural sector's production and affects the sector production through increasing temperatures and climate change (Ochieng et al., 2016). Climate change is caused by industrial activity and greenhouse gas emissions. Industrial activity has increased carbon dioxide levels in the atmosphere by $40 \%$, from $280 \mathrm{ppm}$ to $400 \mathrm{ppm}$ since the beginning of the industrial revolution. Then, greenhouse gas emissions have increased temperatures by $33^{\circ} \mathrm{C}$ in the last 50 years (Kweku et al., 2018). Climate change raises various problems that trigger a decline in agricultural production. For example, an increase in temperature of $0.10^{\circ} \mathrm{C}$ decreases corn and soybean production in southern America by $20.8 \%$ per hectare (Cui, 2020). Also, climate change increases the risk of erosion, loss of nutrients and reduce crop yields (Neset et al., 2019).

Climate change adaptation strategies can be carried out at a macro and micro scale. One form of micro adaptation is autonomous adaptation. Autonomous adaptation is a strategy to minimize the impact of climate change carried out independently by farmers. Autonomous adaptation has several forms: adjusting the cropping system, crop diversification, and improving the irrigation system (Amadou et al., 2018). The implementation of autonomous adaptation reduces the negative impacts of climate change. For example, improved irrigation systems increased rice yields in three cropping systems (direct-seeded, rice intensification system, and alternate wetting and drying) in India by $0.96,0.93$, and 0.77 tonnes/ha, and increased farmers income by 169 USD/ha (Kakumanu et al., 2019). Similarly, adjusting the rice cropping system increased production by 10 to $20 \%$ per hectare, while for annual crops, there was an increase in production by $8 \%$ per hectare (Kawasaki, 2018). Farmer's perceptions of climate change are among the primary factors that encourage farmers to take autonomous adaptation.

Farmers' perceptions of climate change are among the fundamental drivers that drive farmers to implement autonomous adaptation. For example, farmers' perceptions significantly affect farmers' adaptation to climate change in Saesietsaeda Emba, Ethiopia (Gebru et al., 2020). Also, farmers' perceptions of climate affect the form of adaptation carried out by wheat farmers in Uttar Pradesh, India (Singh, 2020). Similarly, farmers' perceptions of climate change risks significantly impact the adaptation decisions taken by wheat farmers in Kermanshah, Iran (Azadi et al., 2019). These findings show that farmers will not implement adaptation strategies if their perceptions toward climate change are weak. Conversely, if the farmers perceive climate change's effect strongly, then the chances of farmers implementing adaptation strategies will be high (Alam et al., 2017). Thus, it is crucial to identify the factors that affect farmers' perception of climate change.

Much research has been carried out to identify factors affecting farmers' perceptions of climate change, both in developing and developed countries. For example, the study of Kabir et al. (2019) on rice farmers in Bangladesh and Wetende et al. (2018) on cereal farmers in Kenya found that several socio-economic factors affect climate change perception. Meanwhile, some examples of research in developed countries are (Mase et al., 2017a), who studied 5000 maize farmers in 22 states in the United States, and (Woods et al., 2017), who studied 1053 farmers in Denmark. However, few studies compare the perceptions of farmers in developed and developing countries simultaneously. Therefore, this study aims to identify the factors influencing farmers' perceptions of climate change, both in developing and developed countries. This research was conducted on cocoa farmers in Ghana and crops and livestock farmers in Switzerland. The results of this study will provide crucial information on the factors that differentiate farmers in developed and developing countries in the face of climate change. Furthermore, this research is necessary because farmers in developing countries are the hardest hit by climate change because of their low adaptability.

\section{METHOD}

Data

This study used data from farmers in Switzerland and Ghana. Swiss farmer data comes from a study by Kreft et al. (2020), while the Ghanaian farmer data comes from a study by 
Oyekale (2020). Data collection in Switzerland was carried out in 2019 on 109 farmers using a combination of census and survey method. The survey consisted of seven sessions, which were then matched with census data for farmer area, land area, farmer type, and farmer age level. Ghanaian farmer data collection was carried out in 2015. The data collection method in Ghana was a structured interview of 378 cocoa farmers in seven districts. The company carries out data collection in the area with the facilities and direct contact with the cocoa farmers. The interview was divided into three sessions: farmers' demographic characteristics, the input of cocoa farming, the vulnerability of farmers, and the adaptation methods used. Table 1 contains the descriptive statistics of the data.

Table 1. Descriptive statistics of the data

\begin{tabular}{|c|c|c|c|c|c|c|c|}
\hline \multirow{2}{*}{ No } & \multirow{2}{*}{ Variable } & \multicolumn{3}{|c|}{ Switzerland } & \multicolumn{3}{|c|}{ Ghana } \\
\hline & & Freq. & Mean & SD & Freq. & Mean & SD \\
\hline \multirow[t]{6}{*}{1} & Perception & & & & & & \\
\hline & $1=$ Very Low Consequences & $2(1.90 \%)$ & & & $108(36.20 \%)$ & & \\
\hline & $2=$ Low Consequences & $12(11.40 \%)$ & & & $39(13.10 \%)$ & & \\
\hline & $3=$ No Consequences & $20(19 \%)$ & & & $56(18.80 \%)$ & & \\
\hline & $4=$ High Consequences & $63(60 \%)$ & & & $45(15.10 \%)$ & & \\
\hline & $5=$ Very High Consequences & $8(7.80 \%)$ & & & $50(16.80 \%)$ & & \\
\hline 2 & Age & & 51 & 9 & & 52 & 13 \\
\hline 3 & Landholding & & 29.46 & 21.67 & & 5.96 & 5.61 \\
\hline \multirow[t]{5}{*}{4} & Education & & & & & & \\
\hline & Primary & $0(0 \%)$ & & & $145(62 \%)$ & & \\
\hline & Secondary & $90(85.70 \%)$ & & & $71(32 \%)$ & & \\
\hline & Tertiary & $6(5.70 \%)$ & & & $18(7.70 \%)$ & & \\
\hline & Others & $9(8.60 \%)$ & & & $0(0 \%)$ & & \\
\hline \multirow[t]{5}{*}{5} & Percent Farm Income & & & & & & \\
\hline & $<26 \%$ & $14(13.30 \%)$ & & & $0(0 \%)$ & & \\
\hline & $26-50 \%$ & $17(16.20 \%)$ & & & $24(9.10 \%)$ & & \\
\hline & $51-75 \%$ & $28(26.70 \%)$ & & & $27(9.10 \%)$ & & \\
\hline & $>75 \%$ & $46(43.80 \%)$ & & & $247(82.90 \%)$ & & \\
\hline \multirow[t]{3}{*}{6} & Crop farming & & & & & & \\
\hline & Practicing & 39 & & & 298 & & \\
\hline & Not Practicing & 66 & & & 0 & & \\
\hline \multirow[t]{4}{*}{7} & Livestock Farming & & & & & & \\
\hline & Practicing & 71 & & & 90 & & \\
\hline & Not Practicing & 34 & & & 208 & & \\
\hline & Sample Size & \multicolumn{3}{|c|}{105} & \multicolumn{3}{|c|}{298} \\
\hline
\end{tabular}

Source: Analyzed raw data from Kreft et al. (2020) \& Oyekale (2020)

Farmers' perception of climate change is divided into five levels: Very Low Consequences (1), Low Consequences (2), No Consequences (3), High Consequences (4), and Very High Consequences (5). Farmers will choose one of the five levels to describe their perception of climate change. The data show that the perceptions of farmers in developed and developing countries are different. There are 60 farmers $(60 \%)$ in Switzerland who perceive a high impact of climate change (4). Twenty farmers (19\%) perceive no impact of climate change (3). Twelve farmers $(11.40 \%)$ perceive a low impact of climate change. Eight farmers $(7.80 \%)$ perceive a very high impact, and only two farmers (1.90\%) perceive a very low impact of climate change. In contrast, 36,20\% of Ghanaian farmers (108 farmers) perceive a very low climate change consequence (level 1), 13.10\% (39 farmers) in level 2, 18.80\% (56 farmers) in level $3,15.10 \%$ (45 farmers) in level 4, and 16,80\% (50 farmers) in level 5.

The average farmer in Switzerland is 51 years old, the minimum farmer in this country is 39 years old, and a maximum of 60 years old, with an average number of landholdings reaching 29.46 ha. Farmers in Ghana have an average age of 52 years with a minimum farmer age of 39 
and a maximum farmer age of 65 years and have an average land area of 5.96 ha. The two countries' education variables are divided into four levels: Primary, Secondary, Tertiary, and Others. 85.70\% (90 farmers) of farmer education level in Switzerland are classified as secondary or equivalent to high school. 5,70\% (6 farmers) belong to the tertiary level or equivalent to the tertiary level, $8.60 \%$ (9 farmers) belong to the others level, and no farmers have primary education or equivalent to junior high school. While the majority of farmers in Ghana $(62 \%, 145$ farmers) are at the primary education level, followed by 71 farmers $(32 \%)$ taking secondary education, and 18 farmers $(7.70 \%)$ are taking tertiary education. No farmers belong to the education level of others.

The farm income variable is used to observe the percentage of farm income to total farmer income. In this variable, four classes are made, the first class is $<26 \%$, the second class is $26-50 \%$, the third class is $51-75 \%$, and the fourth class is $>75 \%$. The total income of farmers in Switzerland and Ghana in the first-class $<26 \%$ is $13.30 \%$ (14 farmers) and $0 \%$. In the second class. Swiss farmers were $16.20 \%$ (17 farmers), while Ghanaian farmers were $9.10 \%$ (24 farmers). The income of farmers in Switzerland and Ghana in the third class of $51-75 \%$ is $26.70 \%$ (28 farmers) and 9.10\% (24 farmers). Forty-six farmers in Switzerland do not raise crops. While a total of 298 farmers in Ghana (100\%) raise crops. Seventy-one farmers $(67.6 \%)$ in Switzerland have livestock farming, and only 34 farmers (32.4\%) farmers in Ghana do not own livestock. However, only 90 farmers in Ghana own livestock (30.2\%), and the remaining 69.8\% (208 farmers) do not. Most of the farmers in Switzerland own the farming and livestock sector. So the income level of farmers in Switzerland is higher than farmers in Ghana.

\section{Variable Descriptions \\ Dependent variable}

The dependent variable in this study is the farmers' perceptions of climate change. The level of farmers' perceptions also affects the adaptation response undertaken by farmers to address climate change. This variable is analyzed using an ordinal scale to indicate the level of perspective on climate change. The measurement used in this variable consists of $1=$ very positive consequences, 2, $3=$ no consequences, and $4,5=$ very negative consequences. This value shows that the greater the size value, the greater the impact felt so that farmers' perceptions of climate change are high. Likewise, on the contrary, the smaller the size value, the impact felt by farmers is small so that farmers' perceptions of climate change are low.

\section{Independent Variable}

The level of farmers' perceptions of climate change is influenced by age, education, land area, percentage of farm income, crop ownership, and livestock ownership. Some of these factors influence farmers' willingness to adapt so that climate change impacts can be minimized. One of these factors is reducing the risk of farmers' risk because farmers' perceptions can encourage farmers to adapt to be stronger and more resistant to climate change stress. This study used six independent variables explained as follows.

\section{a. Age}

Age is one of the factors that influence the level of farmers' perceptions of climate change. Several studies have shown that age is a crucial factor in adapting to climate change. Farmers' age significantly affects climate change adaptation strategies (Marie et al., 2020). Farmers aged 20-30 years have higher awareness and perception levels (Mustafa et al., 2018). This condition is because the older the farmers are, the higher their experience and sensitivity in adapting to climate change, making them more resilient to climate change. Also, study conducted by Assan et al. (2020) shows that farmers with the age of 52 years have low perceptual effectiveness of climate change. 


\section{b. Education}

Education affects farmers' perceptions of climate change. Farmer education has a positive correlation with the ability to access information related to climate change. Farmers with high education can adopt climate change adaptation better than farmers who have low education (Khanal et al., 2018). Smith et al. (2014) show that education significantly affects farmers' motivation to implement climate change adaptation. Education is the primary indicator in influencing farmers' perceptions of climate change. It means that if farmers return to formal education for one year, farmers' awareness and perception of climate change will increase (Fahad et al., 2020).

\section{c. Landholding}

Previous studies have no consensus on the effect of landholding on farmer's perception of climate change. Landholding has positive and negative effects on farmers' perceptions of climate change. Several studies have shown that landholding increase and decrease farmer perceptions of climate change. The area of land owned by farmers does not significantly reduce the impact of climate change. It means that the factor of the land area owned by farmers does not significantly affect farmers' perceptions of climate change.

\section{d. Farm Income}

The amount of income obtained from farming can affect the level of farmers' perceptions of climate change. Changes in rainfall patterns and temperature increase the risk of damage to several agricultural commodities in Iran being damaged and impact, reducing farmers' income (Akbari et al., 2020). Rice farmers in Nigeria have a high perspective on the risk of climate change, so they carry out various adaptations to increase farm yield and income (Ojo \& Baiyegunhi, 2020). A study conducted by Ayanlade et al. (2017) indicates that farmers' income significantly affects climate perception and adaptation types used to deal with climate change.

\section{e. Crop and Livestock Ownership}

Farmers who raise crops, livestock, or both have a different perception of climate change. The agricultural sector is the sector most vulnerable to the risks of climate change (Fahad et al., 2020). A study conducted by Ayanlade et al. (2017) indicates that $67 \%$ of the farmer in Nigeria who raise crops perceive climate change as a danger to their farming. Meanwhile, farmers who raise livestock have a low perception of climate change. The adoption of adaptation to climate change for farmers in Iran is still relatively low. It is evident from the traditional adaptation practices that cannot cope with climate change impacts on livestock (Karimi et al., 2018). A study by Biglari et al. (2019) shows that $4 \%$ of Iran farmers have a high perspective on climate change risk. However, farmers who raise both crops and livestock tend to have a high perception of the risk of climate change (Thamo et al., 2017).

\section{f. Country}

Farmers' perceptions of climate change differ from country to country, especially in developed and developing countries. This condition occurs due to significant differences in the education sector between farmers in developed and developing countries. Ayanlade et al. (2017) indicate that developing countries are more vulnerable to being affected by the risk of climate change, which is more significant than in developed countries. Farmers' perceptions, forms of adaptation, and technology used by farmers in developed countries are better and more advance than in developing countries (Elum et al., 2017).

\section{Empirical Model}

This study used the ordered probit model to estimate factors affecting farmer perception of climate change in Ghana and Switzerland. The ordered probit model is an appropriate regression procedure if the dependent variable is on the ordinal scale. The model used to estimate the ordered probit model is shown in equation 1. 


$$
y_{i}^{*}=\sum_{i=1}^{6} \beta x_{i}+\varepsilon_{i}, \quad i=1,2, \ldots, N
$$

$Y_{i}$ is the farmer's perception of climate change, $\beta$ is the parameter to be estimated, $x$ is the independent variable, and $\varepsilon$ is the error term.

\section{RESULTS AND DISCUSSIONS Results}

This study aimed to estimate the factors affecting farmers' perception of climate change in Switzerland and Ghana. The Switzerland data was collected from farmers in the region of Zürcher Weinland, Canton Zurich, Switzerland. The Zurich Weinland covers an area of $175 \mathrm{~km}^{2}$ and is situated in northern Switzerland. The Zurich Weinland is dominated by the landscapes of Rhine and Thur rivers. Also, the area has the most extensive floodplain in Central Switzerland, the 'Thurauen'. The agriculture in the area is dominated by viticulture and is the primary winegrowing region in the canton of Zurich. Other agricultural products in the area are tobacco, cheese, beer, melons, and asparagus. Meanwhile, the Ghanaian data come from farmers in the Ahafo Ano North District. The area is one of the largest cocoa producers in Ghana. Table 2 shows the estimation results of the ordered probit model in equation 1.

Table 2 Estimation result of the ordered probit model

\begin{tabular}{|c|c|c|c|c|c|c|}
\hline \multirow{2}{*}{ Variable } & \multicolumn{3}{|c|}{ Switzerland } & \multicolumn{3}{|c|}{ Ghana } \\
\hline & $\beta$ & SE & Sig. & $\beta$ & SE & Sig. \\
\hline Threshold very low impact & -2.58 & 1.14 & $0.02 * *$ & -0.93 & 0.43 & $0.03 * *$ \\
\hline Threshold low impact & -1.617 & 1.108 & $0.144^{\mathrm{ns}}$ & -0.537 & 0.435 & $0.216^{\mathrm{ns}}$ \\
\hline Threshold high impact & -0.783 & 1.101 & $0.477^{\mathrm{ns}}$ & -0.008 & 0.434 & $0.985^{\mathrm{ns}}$ \\
\hline Threshold very high impact & 1.409 & 1.104 & $0.202^{\mathrm{ns}}$ & 0.463 & 0.435 & $0.287^{\mathrm{ns}}$ \\
\hline Landholding & -0.013 & 0.006 & $0.039 * *$ & -0.024 & 0.013 & $0.083 *$ \\
\hline Age & -0.002 & 0.015 & $0.912^{\mathrm{ns}}$ & -0.004 & 0.006 & $0.489^{\text {ns }}$ \\
\hline \multicolumn{7}{|l|}{ Education } \\
\hline Primary & & & & -0.215 & 0.278 & $0.44^{\mathrm{ns}}$ \\
\hline Secondary & 1.337 & 0.502 & $0.008 * * *$ & -0.187 & 0.294 & $0.525^{\mathrm{ns}}$ \\
\hline Tertiary & 2.404 & 0.716 & $0.001 * * *$ & & & \\
\hline \multicolumn{7}{|l|}{ Percentage of farm income } \\
\hline$<26 \%$ & -1.068 & 0.44 & $0.015 * *$ & & & \\
\hline $26-50 \%$ & -1.238 & 0.401 & $0.002 * * *$ & -0.63 & 0.263 & $0.017 * *$ \\
\hline $51-75 \%$ & -0.959 & 0.34 & $0.005 * * *$ & -0.981 & 0.292 & $0.001 * * *$ \\
\hline Crop (practicing) & -0.434 & 0.495 & $0.38^{\mathrm{ns}}$ & & & \\
\hline Livestock (practicing) & -0.343 & 0.523 & $0.512^{\mathrm{ns}}$ & 0.054 & 0.12 & $0.729^{\mathrm{ns}}$ \\
\hline \multicolumn{7}{|l|}{ Country (Switzerland) } \\
\hline \multicolumn{7}{|l|}{ Goodness of Fit } \\
\hline Likelihood test ratio & 160.795 & & $0.00 * * *$ & 673.903 & & $0.00 * * *$ \\
\hline Pearson goodness of fit & 348.445 & & $0.14^{\mathrm{ns}}$ & 977.686 & & $0.042 * *$ \\
\hline Deviance goodness of fit & 160.795 & & $1.000^{\mathrm{ns}}$ & 669.509 & & $1.000^{\mathrm{ns}}$ \\
\hline Cox and snell R2 & 0.317 & & & & & 0.103 \\
\hline Nagelkerke R2 & 0.352 & & & & & 0.109 \\
\hline Sample size (n) & & 105 & & & 298 & \\
\hline
\end{tabular}

Note: $* * *$ significant at $1 \%, * *$ significant at $5 \%, *$ significant at $10 \%,{ }^{\text {ns }}$ not significant

Source: Author estimation (2020)

Table 2 shows the results of the estimated analysis of each predictor using ordered probit regression. Because this study describes the factors that affect farmers' perceptions of climate change in two different countries, the analysis presented is divided into two parts with the same variables and analysis model. The study analyze each country's variable value in two different groups: Switzerland and Ghana. Of the 14 variables analyzed in Switzerland and Ghana, 7 and 4 variables were significant, respectively, with 4 and 5 variables showing a positive sign and 10 and 9 predictors showing a negative sign. The likelihood test ratio and Pearson goodness of fit indicate that the analytical model used is appropriate. 
The estimation results are similar for each group of countries in Switzerland and Ghana, indicating that landholding significantly affects farmers' perception of climate change with coefficient values of -0.013 and -0.024 . Also, each group's results show non-significant effect of age on farmer climate risk perception; it means that the age factor did not significantly affect farmers' perception in each country. These results show a significant effect of education in Switzerland, where the country's education level significantly affects farmers' perceptions. The results also show that the higher the farmers' education, the higher the level of significance, which means that farmers' perspective on climate change will also increase. However, different results were found from the results of the analysis in Ghana. The level of education attained by farmers in Ghana does not significantly affect farmers' perceptions of climate change.

In Switzerland and Ghana, each category of farmers' income levels significantly affects farmers' perception of climate change. The results also showed that the higher the percentage of farm income to total income, the farmer's perception of climate change in Switzerland and Ghana would decrease. The estimation results show that crops and livestock ownership did not significantly affects farmer climate risk perception both in Switzerland and Ghana. It means that there is no significant effect for farmers who raise crops and livestock on farmers' perceptions of climate change.

\section{Discussions}

Age

The estimation result shows that age has a non-significant effect on farmer's perception toward climate change both in Switzerland and Ghana. Several studies show that age significantly affects farmers' perception of climate change (Adzawla et al., 2019; Gebru et al., 2020). Furthermore, Koutsou et al. (2014) stated that young farmers have a better perception and adaptation to climate change. Young farmers can access scientific information quickly and adept at operating modern technology. Furthermore, Marie et al. (2020) state that if there is an increase in the age of the head of farm households, it will increase the probability of adapting to climate change by $1.9 \%$. However, our study confirms the result of Mase et al. (2017b) who studied farmers in America found that age does not significantly affect farmers' perceptions of climate change.

The results show that age has an insignificant effect on farmers' perceptions of climate change. The insignificant results in the partial analysis indicate differences in the quality of education in Switzerland and Ghana. Most Swiss farmers have professional certificates. It means that before becoming farmers, they have taken professional farmer education. Thus, both young and old farmers have a good ability to use technology and access information related to climate change. Thus, this condition causes age not to affect farmers' perceptions of climate change significantly. On the other hand, in Ghana, most farmers have low education, so both young and old farmers tend to have low sensitivity and awareness of climate change.

\section{Landholding}

The estimation results show that landholding has a significant effect. In general, landholding affects farmers' perceptions and encourages farmers to adapt to climate change. Khan et al. (2020) state that landholding affects farmers' perceptions of climate change and adaptation forms. In line with these results, Marie et al. (2020) state that landholding has a significant effect on farmers' perceptions and adaptation methods. Landholding also positively affects farmers' awareness of climate change (Mustafa et al., 2018). This study's results are in line with several previous studies that state that landholding has a significant effect on farmers' perceptions of climate change. Also, the coefficient of land area for Swiss farmers is higher than that of Ghanaian farmers. It means that farmers in Switzerland have a stronger perception of climate change than farmers in Ghana because they have a more extensive average landholding. 


\section{Education}

The estimation results show a significant effect on farmer education in Switzerland, while farmer education in Ghana shows an insignificant effect. For farmers in Switzerland, the tertiary education category has the highest significance. It means that farmers' perceptions of climate change increase with the higher education of farmers. In general, farmer education has a significant effect on the sensitivity and form of farmers (Marie et al., 2020). Farmers 'education is a determining factor for farmers' awareness of climate change and adaptation strategy selection. Fahad et al. (2020) show a positive relationship between farmer perceptions and farmer education. It means that farmers' perceptions of climate change will be stronger if they attend education. The head of the household's education has a significant effect on the form of adaptation of farmers to climate change. Also, farm households with high education tend to implement advanced adaptation strategies requiring knowledge and expertise in implementing those adaptation technologies (Huong et al., 2019).

This study indicates that education has a significant effect in Switzerland, while it does not significantly affect Ghana. This result is due to differences in the quality of education in Switzerland and Ghana. It means that the quality of education in Switzerland is higher than the quality of education in Ghana. Thus, farmers in Switzerland are more capable of realizing climate change as a threat to farming. Jiménez et al. (2015) state that improving the education system's quality and efficiency is an important country's policy to improve human resources and income per capita.

\section{Farm Income}

Farm production affects farm income. Thus, the farmer takes various efforts to maintain and increase production to maintain their income stability. Climate change adversely affects farm production, which encourages farmers to implement various adaptation strategies to maintain farmers' income. Farmers who implement climate change adaptation strategies have a higher income than farmers who do not implement them (Khanal et al., 2018). These findings indicate that farm income is one of the factors driving farmers to implement adaptation strategies. Alam et al. (2017) show a relationship between production yields, income, and farmers' vulnerability to climate change. Farmers' income also affects the adaptation strategy selection and farmer sensitivity to climate change. Jamshidi et al. (2019) show that farmer has a high adaptive capacity due to farmers' high income. It means that the higher the farmers' income, the higher the farmers' perception of climate change. However, several other studies show that farmers' motivation to implement climate change adaptation strategies is due to reduced income caused by climate change. The estimation results show that farm income has a significant effect. The highest level of significance in Switzerland lies in the 26-50\% category or low-income group. It means that the lower the farmer's income, the farmer's perception of climate change will increase. Meanwhile, the highest significance of Ghanaian farmers lies in the $51-75 \%$ category or high-income group. It means that farmers 'perceptions of climate change increase when farmers' incomes are high.

\section{Crops and Livestock ownership}

The results of crop and livestock estimation showed insignificant results. It means that the ownership of crops, livestock, or both have no significant effect on farmers' perceptions of climate change. In general, there are different perceptions between farmers who only raise crops, livestock, or both. Ayanlade et al. (2017) show that farmers who only raise crops have the highest level of perception (48\%) compared to livestock (17.8\%) and farmers who own both (34\%). This condition is caused by crops that are more susceptible to climate change than livestock. Thus, the climate change adaptation strategy is more widely applied by farmers who raise crops than livestock. 


\section{CONCLUSION}

This study aims to identify the factors influencing farmers' perceptions of climate change in developed and developing countries. The study used data from farmers in Switzerland and Ghana. This study indicates landholding and the percentage of farm income significantly affect farmers' perceptions of climate change in Switzerland and Ghana. Meanwhile, age, crop/livestock ownership showed insignificant results in both Switzerland and Ghana. Meanwhile, education shows a significant effect in Switzerland but not significant in Ghana. These results have several crucial implications for the agriculture in Switzerland and Ghana in relation to the climate change. The implications are:

a. For Ghana, farmer knowledge is the main driver of climate risk perception. However, the formal education alone cannot improve farmer perception toward climate change. Thus, there is a strong need for an informal education system for farmer to educate farmer both on the threat and adaptation practices to mitigate the effect of climate change.

b. For Switzerland, it is important to strengthen the adaptation practices of highly educated farmer since those farmers are more sensitive to climate change.

\section{REFERENCES}

Adzawla, W., Kudadze, S., Mohammed, A. R., \& Ibrahim, I. I. (2019). Climate perceptions, farmers' willingness-to-insure farms and resilience to climate change in Northern region, Ghana. Environmental Development, 100466. https://doi.org/10.1016/j.envdev.2019.100466

Akbari, M., Najafi Alamdarlo, H., \& Mosavi, S. H. (2020). The effects of climate change and groundwater salinity on farmers' income risk. Ecological Indicators, 110(February 2019). https://doi.org/10.1016/j.ecolind.2019.105893

Alam, G. M. M., Alam, K., \& Mushtaq, S. (2017). Climate Risk Management Climate change perceptions and local adaptation strategies of hazard-prone rural households in Bangladesh. Climate Risk Management, 17, 52-63. https://doi.org/10.1016/j.crm.2017.06.006

Amadou, M. L., Villamor, G. B., \& Kyei-Baffour, N. (2018). Simulating agricultural land-use adaptation decisions to climate change: An empirical agent-based modelling in northern Ghana. Agricultural Systems, 166(October 2017), 196-209. https://doi.org/10.1016/j.agsy.2017.10.015

Assan, E., Suvedi, M., Schmitt Olabisi, L., \& Bansah, K. J. (2020). Climate change perceptions and challenges to adaptation among smallholder farmers in semi-arid Ghana: A gender analysis. Journal of Arid Environments, 182(June), 104247. https://doi.org/10.1016/j.jaridenv.2020.104247

Ayanlade, A., Radeny, M., \& Morton, J. F. (2017). Comparing smallholder farmers' perception of climate change with meteorological data: A case study from southwestern Nigeria. Weather and Climate Extremes, 15(September), 24-33. https://doi.org/10.1016/j.wace.2016.12.001

Azadi, Y., Yazdanpanah, M., \& Mahmoudi, H. (2019). Understanding smallholder farmers ' adaptation behaviors through climate change beliefs, risk perception, trust, and psychological distance: Evidence from wheat growers in Iran. Journal of Environmental Management, 250(July), 109456. https://doi.org/10.1016/j.jenvman.2019.109456

Biglari, T., Maleksaeidi, H., Eskandari, F., \& Jalali, M. (2019). Livestock insurance as a mechanism for household resilience of livestock herders to climate change: Evidence from $\begin{array}{llll}\text { Iran. } \quad \text { Land } & \text { Policy, } & \text { 87(March), } & 104043 .\end{array}$ https://doi.org/10.1016/j.landusepol.2019.104043

Cui, X. (2020). Climate change and adaptation in agriculture: Evidence from US cropping patterns. Journal of Environmental Economics and Management, 101, 102306. https://doi.org/10.1016/j.jeem.2020.102306

Elum, Z. A., Modise, D. M., \& Marr, A. (2017). Farmer's perception of climate change and 
responsive strategies in three selected provinces of South Africa. Climate Risk Management, 16, 246-257. https://doi.org/10.1016/j.crm.2016.11.001

Fahad, S., Inayat, T., Wang, J., Dong, L., Hu, G., Khan, S., \& Khan, A. (2020). Farmers' awareness level and their perceptions of climate change: A case of Khyber Pakhtunkhwa province, Pakistan. Land Use Policy, 96(April), 104669. https://doi.org/10.1016/j.landusepol.2020.104669

Gebru, G. W., Ichoku, H. E., \& Phil-Eze, P. O. (2020). Determinants of smallholder farmers' adoption of adaptation strategies to climate change in Eastern Tigray National Regional State of Ethiopia. Heliyon, 6(7), e04356. https://doi.org/10.1016/j.heliyon.2020.e04356

Huong, N. T. L., Bo, Y. S., \& Fahad, S. (2019). Economic impact of climate change on agriculture using Ricardian approach: A case of northwest Vietnam. Journal of the Saudi Society of Agricultural Sciences, 18(4), 449-457. https://doi.org/10.1016/j.jssas.2018.02.006

Jamshidi, O., Asadi, A., Kalantari, K., Azadi, H., \& Scheffran, J. (2019). Vulnerability to climate change of smallholder farmers in the Hamadan province, Iran. Climate Risk Management, 23(August 2017), 146-159. https://doi.org/10.1016/j.crm.2018.06.002

Jiménez, A., Palmero-Cámara, C., González-Santos, M. J., González-Bernal, J., \& JiménezEguizábal, J. A. (2015). The impact of educational levels on formal and informal entrepreneurship. BRQ Business Research Quarterly, 18(3), 204-212. https://doi.org/10.1016/j.brq.2015.02.002

Kabir, M. J., Cramb, R., Alauddin, M., \& Gaydon, D. S. (2019). Farmers' perceptions and management of risk in rice-based farming systems of south-west coastal Bangladesh. Land Use Policy, 86(December 2018), 177-188. https://doi.org/10.1016/j.landusepol.2019.04.040

Kakumanu, K. R., Kaluvai, Y. R., Balasubramanian, M., Nagothu, U. S., Kotapati, G. R., \& Karanam, S. (2019). ADAPTATION TO CLIMATE CHANGE: IMPACT OF CAPACITY BUILDING, INDIA. Irrigation and Drainage, 68(1), 50-58. https://doi.org/10.1002/ird.2275

Karimi, V., Karami, E., \& Keshavarz, M. (2018). Vulnerability and Adaptation of Livestock Producers to Climate Variability and Change. Rangeland Ecology and Management, 71(2), 175-184. https://doi.org/10.1016/j.rama.2017.09.006

Kawasaki, K. (2018). Two Harvests Are Better than One: Double Cropping as a Strategy for Climate Change Adaptation. American Journal of Agricultural Economics, O(July), 1-21. https://doi.org/10.1093/ajae/aay051

Khan, I., Lei, H., Shah, I. A., Ali, I., Khan, I., Muhammad, I., Huo, X., \& Javed, T. (2020). Farm households' risk perception, attitude and adaptation strategies in dealing with climate change: Promise and perils from rural Pakistan. Land Use Policy, 91(October 2019), 104395. https://doi.org/10.1016/j.landusepol.2019.104395

Khanal, U., Wilson, C., Hoang, V. N., \& Lee, B. (2018). Farmers' Adaptation to Climate Change, Its Determinants and Impacts on Rice Yield in Nepal. Ecological Economics, 144(February 2017), 139-147. https://doi.org/10.1016/j.ecolecon.2017.08.006

Koutsou, S., Partalidou, M., \& Ragkos, A. (2014). Young farmers' social capital in Greece: Trust levels and collective actions. Journal of Rural Studies, 34, 204-211. https://doi.org/10.1016/j.jrurstud.2014.02.002

Kreft, C. S., Huber, R., Wüpper, D. J., \& Finger, R. (2020). Data on farmers' adoption of climate change mitigation measures, individual characteristics, risk attitudes and social influences in a region of Switzerland. Data in Brief, 30, 105410. https://doi.org/10.1016/j.dib.2020.105410

Kweku, D., Bismark, O., Maxwell, A., Desmond, K., Danso, K., Oti-Mensah, E., Quachie, A., \& Adormaa, B. (2018). Greenhouse Effect: Greenhouse Gases and Their Impact on Global Warming. Journal of Scientific Research and Reports, 17(6), 1-9. https://doi.org/10.9734/jsrr/2017/39630

Marie, M., Yirga, F., Haile, M., \& Tquabo, F. (2020). Farmers' choices and factors affecting 
adoption of climate change adaptation strategies: evidence from northwestern Ethiopia. Heliyon, 6(4), e03867. https://doi.org/10.1016/j.heliyon.2020.e03867

Mase, A. S., Gramig, B. M., \& Prokopy, L. S. (2017a). Climate change beliefs, risk perceptions, and adaptation behavior among Midwestern U.S. crop farmers. Climate Risk Management, 15, 8-17. https://doi.org/10.1016/j.crm.2016.11.004

Mase, A. S., Gramig, B. M., \& Prokopy, L. S. (2017b). Climate change beliefs, risk perceptions, and adaptation behavior among Midwestern U.S. crop farmers. Climate Risk Management, 15, 8-17. https://doi.org/10.1016/j.crm.2016.11.004

Mustafa, G., Latif, I. A., Bashir, M. K., Shamsudin, M. N., \& Daud, W. M. N. W. (2018). Determinants of farmers' awareness of climate change. Applied Environmental Education \& Communication, O(0), 1-15. https://doi.org/10.1080/1533015X.2018.1454358

Neset, T. S., Wiréhn, L., Opach, T., Glaas, E., \& Linnér, B. O. (2019). Evaluation of indicators for agricultural vulnerability to climate change: The case of Swedish agriculture. Ecological Indicators, 105(May 2017), 571-580. https://doi.org/10.1016/j.ecolind.2018.05.042

Ochieng, J., Kirimi, L., \& Mathenge, M. (2016). Effects of climate variability and change on agricultural production: The case of small scale farmers in Kenya. NJAS - Wageningen Journal of Life Sciences, 77, 71-78. https://doi.org/10.1016/j.njas.2016.03.005

Ojo, T. O., \& Baiyegunhi, L. J. S. (2020). Determinants of climate change adaptation strategies and its impact on the net farm income of rice farmers in south-west Nigeria. Land Use Policy, 95(November 2018), 103946. https://doi.org/10.1016/j.landusepol.2019.04.007

Oyekale, A. S. (2020). Dataset on cocoa production and climate change adaptation strategies in Ahafo Ano North District, Ghana. Data in Brief, 29, 105275. https://doi.org/10.1016/j.dib.2020.105275

Singh, S. (2020). Farmers' perception of climate change and adaptation decisions: A microlevel evidence from Bundelkhand Region, India. Ecological Indicators, 116(April), 106475. https://doi.org/10.1016/j.ecolind.2020.106475

Smith, W. J., Liu, Z., Safi, A. S., \& Chief, K. (2014). Climate change perception, observation and policy support in rural Nevada: A comparative analysis of Native Americans, nonnative ranchers and farmers and mainstream America. Environmental Science and Policy, 42, 101-122. https://doi.org/10.1016/j.envsci.2014.03.007

Thamo, T., Addai, D., Pannell, D. J., Robertson, M. J., Thomas, D. T., \& Young, J. M. (2017). Climate change impacts and farm-level adaptation: Economic analysis of a mixed cropping-livestock system. Agricultural Systems, 150, 99-108. https://doi.org/10.1016/j.agsy.2016.10.013

Woods, B. A., Nielsen, H. Ø., Pedersen, A. B., \& Kristofersson, D. (2017). Farmers' perceptions of climate change and their likely responses in Danish agriculture. Land Use Policy, 65(March), 109-120. https://doi.org/10.1016/j.landusepol.2017.04.007 